\title{
Like Islam Project, Strategi Dakwah Masa Kini
}

\section{Syahida Yasya Moeniri}

syahida.yasyamoeniri@gmail.com

Institut Dirosat Islamiyah Al-Amien Prenduan Sumenep Madura

\begin{abstract}
Islam is the religion with aesthetics. It is Muslim's obligation to generously spread the beauty of Islamic teachings in all aspects of life, health, education and economy. For that reason, Like Islam Project tries to promote da'wah Islam through its business, a creative home industry. Like Islam Project uses Islamic quotes in their merchandise products to convey Islamic teachings. This study is a qualitative descriptive study. Data is collected through faceto-face interview with the owner and an online interview, using Whatsappplatform, with 2 of their resellers. To validate observation and documentation are performed. Result shows that Like Islam Project has special strategies to reach their goals. Those strategies are clear intention, qualified human resources, setting da'wah targets, selecting appropriate media, and also having original idea and concept. Background and da'wah style of Like Islam Project are also discussed.
\end{abstract}

Keywords: Like Islam Project, da'wah strategy 


\title{
6o-74 | Syahida Yasya Moeniri
}

\begin{abstract}
Abstrak Islam adalah agama yang penuh dengan estetika, maka dari itu wajib bagi seluruh umat Islam menyebarkan Islam dengan cara yang baik dan indah di segala aspek kehidupan, entah itu kesehatan, pendidikan ataupun ekonomi. Berani menyisipkan dakwah di dalam bisnis tanpa mengurangi niat dakwah merupakan pilihan Like Islam Project sebagai home industry kreatif. Like Islam Project menyebarkan dakwahnya dengan menggunakan produk merchandise yang berisi Islamic quotes. Metode Penelitian ini menggunakan metodekualitatif deskriptif. Teknik pengumpulan data yang digunakan oleh peneliti adalah wawancara secara lisan yang langsung dilakukan ke sumber informasi yakni owner Like Islam Project dan secara tulisan dengan menggunakan media sosial whats app kepada 2 reseller. Selain itu peneliti juga menggunakan metode observasi dan dokumentasi untuk memvalidasi hasil wawancara dengan kenyataan yang terjadi. Penulis menemukan bahwa Like Islam Project memiliki strategistrategi khusus untuk mencapai tujuan dakwahnya, utamanya yakni dengan memiliki visi atau niat yang jelas, lalu diikuti dengan dengan menyiapkan sumber daya manusia yang berkualitas, menentukan target dakwah, memilih media yang sesuai dengan kondisi dan situasi, serta memiliki originalitas ide dan konsep. Beberapa hal penting lainnya juga dibahas dalam penulisan ini, terkait dengan latar belakang dan bentuk dakwah Like Islam Project.
\end{abstract}

\section{Kata Kunci: Like Islam Project, Strategi Dakwah}

\section{Pendahuluan}

Dakwah adalah segala bentuk aktivitas penyampaian ajaran Islam kepada orang lain dengan berbagai cara yang bijaksana untuk terciptanya individu dan masyarakat yang menghayati dan mengamalkan ajaran Islam dalam semua lapangan kehidupan.Dakwah merupakan kewajiban bagi umat Islam tak terkecuali.

Dakwah telah berlangsung melalui proses masyarakat yang amat panjang dan beragam. Sejak masa Nabi Muhammad sampai masa peradaban manusia saat ini, dakwah telah mencapai tingkatan yang tinggi. Karena pertimbangan itulah, barangkali sejumlah ahli kemudian berijtihad tentang pendekatan dakwah pada masyarakat industri dan era informasi;

${ }^{1}$ Moh. Ali Aziz, Ilmu Dakwah, (Jakarta: Kencana, 2004), h. 11. 
Syahida Yasya Moeniri: Like Islam Project | 61-74

bagaimana Islam ditransformasikan kepada masyarakat dengan segala corak kebudayaan, karena dinamika selalu berubah sekaligus melahirkan problematikanya yang semakin kompleks. ${ }^{2}$

Ledakan informasi merupakan pertanda dari peluang dan tantangan yang akan dihadapi masyarakat di masa depan. Pembengkakan volume informasi yang dicetuskan, dipindahkan, dan diterima akan terus dan semakin menggelembung. Seiring dengan itu, makna informasi pun meningkat pula. Pada masa itu, manusia akan hidup dalam suatu tatanan masyarakat baru, yaitu masyarakat informasi. ${ }^{3}$

Tidak hanya dilihat dari peradaban masyarakat secara umum, tetapi mad'ū (objek dakwah) juga dibagi menjadi bermacam-macam golongan manusia, salah satunya yaitu dari segi tingkatan usia, ada golongan anakanak, remaja dan golongan orang tua. Di era informasi dan teknologi,

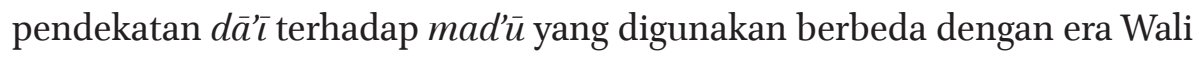
Songo, begitu juga pendekatan terhadap remaja berbeda dengan anakanak atau orang tua.

Pada dasarnya dakwah bisa menggunakan berbagai wasīlah yang dapat menarik perhatian mad'ü untuk menerima dakwah. Semakin tepat media yang dipakai, maka semakin efektif pula dakwah yang dilakukan. Media (terutama media massa) telah meningkatkan intensitas, kecepatan, dan jangkauan komunikasi yang dilakukan dầ terhadapmad'ū, terlebih lagi dengan adanya media massa seperti pers, radio, televisi, internet dan sebagainya. Bahkan dapat dikatakan alat-alat tersebut tidak dapat dipisahkan dari kehidupan manusia di zaman ini, khususnya internet.

Agama on-line, atau lebih khusus lagi ekspresi spritualitas atau religiusitas dan komunitas keyakinan on-line, hadir secara melimpah ruah di jaringan World Wide Web dan juga di berita-berita serta grup-grup chat internet. Dengan penerbitan khusus majalah Time mengenai agama online pada 1996, terbukti banyak sekali situs keagamaan dan sumber-sumber

\footnotetext{
${ }^{2}$ Asep Saeful Muhtadi dan Agus Ahmad Safei, Metode Penelitian Dakwah, (Bandung: Pustaka setia, 2003), h. 24.

3 Abdul Karim Batubara, "Pemanfaatan Media Komunikasi Massa Sebagai Sumber Informasi”, Iqra', Volume o2 Nomor o1, (2008), h. 74.
} 


\section{2-74 | Syahida Yasya Moeniri}

online keagamaan bisa ditemukan. ${ }^{4}$ Maka merupakan peluang besar bagi seorang $d \bar{a} \mathfrak{\imath}$ untuk menggunakan media internet sebagai wasillah dalam berdakwah, sebab dengan pemanfaatan teknologi modern sebagai media dakwah, maka dakwah akan diterima dalam skala yang sangat luas dan dalam waktu yang cukup singkat.

Dakwah bisa disampaikan melalui komunikasi visual. Komunikasi visual merupakan komunikasi yang menggunakan unsur dasar bahasa visual sebagai kekuatan utamanya dalam menyampaikan komunikasi. Unsur dasar visual tersebut ialah segala sesuatu yang dapat dilihat dan dapat dipakai untuk menyampaikan arti, makna, serta pesan dan medianya. ${ }^{5}$ Pada zaman yang serba praktis ini manusia lebih menyukai sesuatu yang memiliki efektivitas. Efektivitas dapat dicapai dengan mengkomunikasikan suatu informasi atau pesan secara visual.

Dalam menyampaikan pesan dibutuhkan kreativitas untuk menciptakan sesuatu yang baru, sehingga orang-orang akan tertarik dengan dakwahnya. Kreativitas menciptakan nilai tambah pada sesuatu yang biasa. Kreativitas identik dengan harus beda (unique selling preposition); sementara itu, masalah fungsi itu juga merupakan suatu konsep dan keterampilan yang built-in dalam proses kreatif. Aspek kreatif pada unique selling preposition berorientasi pada keunggulan atau kelebihan produk yang tidak dimiliki oleh produk saingannya. Kelebihan tersebut juga merupakan sesuatu yang dicari atau dijadikan alasan bagi konsumen untuk menggunakan suatu produk. ${ }^{6}$

Berdasarkan pernyataan masalah tersebut, maka "\#Like Islam Project" yang merupakan industri kreatif yang mengemas pesan Islamic reminder dalam sebuah desain visual yang diaplikasikan menjadi $t$-shirt, totebag, pouch, dan produk marchandise lainnya. "\#Like Islam Project" mempublikasikan karyanya 9o\% di media internet, seperti instagram, Line, WA, dan Facebook. Peniliti merasa bahwa media dakwah yang digunakan

${ }^{4}$ Idi Susbandy Ibrahim dan Bachruddin Ali Akhmad, Komunikasi dan Komodifikasi, (Jakarta: Yayasan Pustaka Obor, 2014), h. 132.

${ }^{5}$ Heru Dwi Waluyanto, "Komik Sebagai Media Komunikasi Visual Pembelajaran", Nirmana, Vol. 7, No. 1, (Januari, 2005), h. 45.

${ }^{6}$ Ibid., h. 47 . 
Syahida Yasya Moeniri: Like Islam Project | 63-74

di era internet ini sangat layak untuk diteliti lebih jauh, terkait pula dengan produk marchandise yang mengandung komunikasi visual dalam setiap produknyadan bersifat Islamic Reminder. Selain itu, Like Islam Project merupakan media dakwah melalui online store yang sudah sangat terkenal di kalangan anak muda di Indonesia hingga Luar Negeri. Hal ini juga yang mendorong penulis untuk meneliti lebih jauh bagaimana strategi yang digunakan \#Like Islam Project dalam dakwahnya di masa kini.

\section{Pembahasan}

\section{Latar Belakang Terbentuknya Like Islam Project}

Latar belakang terbentuknya online store Like Islam Project ini dilandasi oleh beberapa motif yakni:

\section{a. Dakwah merupakan kewajiban seluruh muslim}

Dakwah merupakan sebuah kewajiban bagi seluruh umat muslim tak terkecuali. Untuk berbagi inspirasi dan kebaikan tidak harus selalu lulusan pesantren atau perguruan tinggi Islam, semua muslim berhak untuk melakukan dakwah. Begitu juga yang dirasakan oleh Antika bahwa ia wajib ikut andil dalam menyeru umat pada kebaikan. Begitu juga Allah memerintahkan umat nabi Muhammad untuk berdakwah dalam surat QS. An-Nahl/ 16:125.

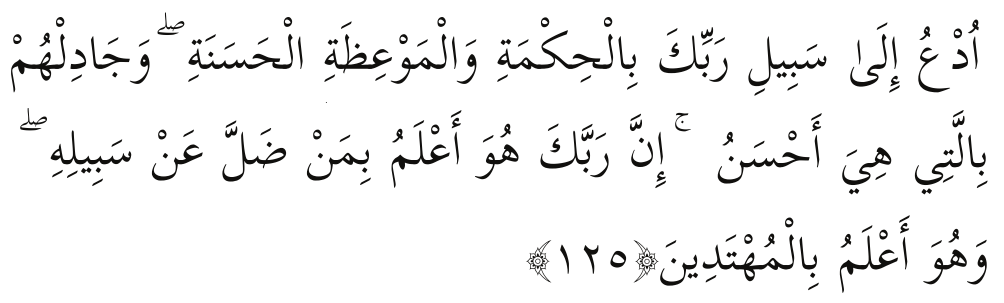

"Serulah (manusia) kepada jalan Tuhan-mu dengan hikmah dan pelajaran yang baik dan bantahlah mereka dengan cara yang baik. Sesungguhnya Tuhanmu Dialah yang lebih mengetahui tentang siapa yang tersesat dari jalan-Nya dan Dialah yang lebih mengetahui orang-orang yang mendapat petunjuk."7

${ }^{7}$ Departemen Agama RI, Al-H\}ikmah al-Qurān dan Terjemahnya (Bandung: Diponegoro, 2010), h. 281 
64-74 | Syahida Yasya Moeniri

Dakwah dengan ceramah hanya bisa dilakukan oleh orang-orang yang memiliki pengaruh seperti kyai atau ustadz, padahal semua muslim wajib untuk berdakwah. Dakwah tidak hanya bisa dilakukan dengan memberi tausiyah, dakwah bisa kita sisipkan di semua sisi kehidupan manusia. Seorang fotografer juga bisa berbagi inspirasi kebaikan, bagaimana caranya ? jika fotografer hewan, dia bisa memamerkan hasil jepretan foto hewannya melalui suatu pameran fotografi. Kemudian, di dalam gambar hewan itu dia menyelipkan pesan-pesan dakwah yang bisa dilihal oleh semua orang. ${ }^{8}$ Hal seperti inilah yang dilakukan oleh Antikah lewat online store Like Islam Project, ia membuat suatu produk marchandise yang berisi Islamic quotes yang ia jual kepada orangorang sehingga orang yang menggunakannya akan terinspirasi dengan dakwahnya dan begitu juga orang yang melihat produk tersebut.

Berangkat dari pengajian yang diikuti oleh saudari Antikah yang memiliki visi misi untuk berdakwah, maka dia dan suaminya juga ingin berdakwah dengan produk mereka dan memberikan efek yang positif bagi orang lain.

\section{b. Untuk memenuhi kebutuhan hidupnya}

Berangkat dari keinginan untuk mencari kerja untuk memenuhi kebutuhannya, Antikah akhirnya bertemu dengan Ade, suaminya sekarang yang mahir di bidang desain, sehingga terpikirkan untuk membuat usaha yang berbeda dari yang lain. Awalnya mereka ingin membuka usaha kaos dengan Islamic quotes, namun karena melihat pangsa perempuan lebih menguntungkan, maka terpikirlah untuk membuat totebag yang berisi Islamic Quotes.

Antikah dalam prosesnya mencari pekerjaan tetap lebih mementingkan agamanya, terbukti dengan Antikah yang tetap berpegang teguh menggunakan gamis dan jilbab yang lebar hingga akhirnya ia menemukan bisnis sebagai pekerjaan yang aman untuk menjaga konsistennya menjaga aurat.

\footnotetext{
${ }^{8}$ Fadil Ibnu Ahmad, Dakwah Online, (Bandung: Mizania, 2014), h. 17-18.
} 


\section{c. Terbentuk dari akun dakwah \#likeislam}

Like Islam Project ini dibentuk dari akun dakwah milik Antikah di instgram yakni \#likeislam. Akun Like Islam ini berisi tentang gambargambar dan video-video beserta penjelasan dari Antikah dan sebagai media sharing tentang ilmu. Awalnya Antikah ingin memberi nama akun dakwahnya dengan Love Islam tetapi sudah terdapat banyak akun yang menggunakan nama tersebut, maka dari itu Antikah memilih kata "Like" yang memiliki arti yang sama dengan "Love". Dinamakan Like Islam Project karena bisnis ini merupakan proyek dari akun Like Islam. Like Islam Project dan Like Islam sama-sama memiliki tujuan untuk berdakwah namun dengan media yang berbeda dengan Like Islam, yakni dengan media marchandise.

\section{d. Online store lebih efektif di era yang penuh dengan teknologi}

Dari masa ke masa, teknologi komunikasi semakin berkembang, khususnya intenet. Hal ini banyak dimanfaatkan oleh orang-orang dalam segala aktifitas mereka, dari bangun tidur hingga tidur lagi, serta dari berbagai sisi kesehatan, pendidikan, bisnis bahkan dakwah seperti akun instagram Like Islam yang merupakan akun dakwah miliki Antikah juga. Dari akun ini lah terbentuk Like Islam Project. Like Islam Project juga ikut berpartisipasi dalam penggunann internet, khususnya media sosial seperti instagram, whats app, line, dan facebook dalam memasarkan produknya. Menggunakan internet memberikan kemudahan dalam pemasaran produk Like Islam Project karena di zaman ini, informasi semakin mudah kita dapatkan melalui internet yang sudah biasa di akses dari ponsel, kita bisa mengaksesnya di mana pun dan kapan pun. ${ }^{9}$

\section{Strategi Dakwah Like Islam Project}

Penyampaiannya komunikasi tidak selalu berhasil, banyak hambatan yang membuatnya gagal, untuk itu diperlukan strategi untuk menyampaikan informasi kepada komunikan agar pesan bisa sukses diterima oleh komunikan.

\footnotetext{
${ }^{9}$ Ibid., h. 23 .
} 
66-74 | Syahida Yasya Moeniri

Strategi menurut Arifin ${ }^{10}$ adalah keseluruhan keputusan kondisional tentang tindakan yang akan dijalankan, guna mencapai tujuan. Jadi, merumuskan strategi dakwah, berarti memperhitungkan kondisi dan situasi (ruang dan waktu) yang dihadapi di masa depan, guna mencapai efektivitas atau mencapai tujuan.

Strategi dakwah Like Islam Project yang peneliti paparkan pada pembahasan ini merupakan strategi yang dilakukan owner Like Islam Project dan tim dalam mencapai visinya yakni berdakwah dengan ramah dan memberikan efek positif bagi orang lain pada masa yang penuh dengan teknologi dan informasi seperti saat ini. Adapun strategi-strategi yang dilakukan adalah:

\section{a. Memiliki Visi yang Jelas}

Sebelum pelaksanaan dakwah dilakukan tentu ditata terlebih dahulu niat yang baik, oleh karena itu niat yang baik adalah suatu ketentuan justifikasi yang bersifat normatif."Begitu juga Antikah memiliki visi membentuk Like Islam Project yaitu:

1. Spread with SerSaNi (Serius, Santai dan Syar'i)

2. Mengajak dan menjadikan hidup pelanggan lebih islami dengan menggunakan bank syari'ah

3. Menjadi inspirasi dan do'a bagi reseller dan pelanggan

4. Sebagai sarana memperkenalkan akun dakwah Like Islam

Disamping justifikasi normatif, secara psikologis niat menjadi reinforcement atau peneguhan dalam setiap pelaksanaan dakwah sehingga optimalisasi pelaksanaan dengan hasil yang diharapkan dapat tercukupi, karena setiap langkah pelaksanaan akan dibimbing oleh keberadaan niat yang baik itu. ${ }^{12}$

\section{b. Menyiapkan Sumber Daya Manusia (Mubaligh) yang Berkualitas}

Untuk mencapai tujuan dakwah, maka unsur yang dibutuhkan pertama kali adalah seorang dā̄t. Like Islam Project memiliki sumber daya manusia yang berkualitas, diantaranya:

\footnotetext{
${ }^{10}$ Anwar Arifin, Dakwah Kontemporer, (Yogyakarta: Graha Ilmu, 2011), h. 227

${ }^{11}$ Hasyim Syamhudi, Manajemen Dakwah, (Surabaya, elkaf, 2007), h. 29.

${ }^{12}$ Ibid., h. 29-30.
} 
1. Seorang pelaku dakwah harus expert dalam bidangnya.

2. Memiliki rasa optimisme, tidak kenal putus asa, dan berani menerima kegagalan untuk bisa menjadi lebih baik.

3. Pandai melihat peluang dalam setiap situasi dan kondisi.

4. Memiliki sifat-sifat yang sangat dianjurkan oleh Islam seperti sabar, tawakal, selalu bersyukur, berani dan berpikir positif, dll.

5. Berjiwa besar menerima kritikan dari berbagai pihak.

Amin $^{13}$ menyebutkan sifat-sifat yang harus dimiliki pendakwah adalah beriman dan bertaqwa kepada Allah, Ikhlas, ramah dan penuh pengertian, tawadhu' dan rendah hati, sederhana dan jujur dalm bertindak, tidak egois, semangat dalm berdakwah, tawakkal dalam berdakwah, penuh toleransi, terbuka dan demokratis, serta berusaha bersih dari berbagai penyakit hati.

Dalam menjalankan dakwah dibutuhkan manajemen yang memiliki sifat-sifat leadership diantaranya ${ }^{14}$ :

1. Berpengetahuan luas, kreatif, peka dan inisiatif

2. Lapang dada dan berpandangan luas

3. Melaksanakan amanah/ program atau planning

4. Bertindak adil

5. Selektif terhadap informasi

6. Memberi peringatan

7. Memberi petunjuk dan pengarahan

Jika semua faktor dilaksanakan oleh pimpinan dan segenap anggotanya, dengan penuh rasa tanggung jawab maka akan terciptalah mekanisasi roda kepemimpinan yang harmonis, berjalan lancar, tertib, dengan demikian keberhasilan dan kemenangan akan mudah dicapai sebagai tujuan utama.

\section{c. Menentukan Target (Mad'ū)}

Manusia diciptakan dengan watak dan kepribadian yang berbeda. Untuk mencapai tujuan dakwah, maka perlu menentukan target dakwah, karena setiap target memiliki karakteristik yang

${ }^{13}$ Akhmad Anwar Dani, Ilmu Dakwah, (Pamekasan: Cendekia, 2014), h. 1.

${ }^{14}$ Hasyim Syamhudi, Manajemen Dakwah, (Surabaya, elkaf, 2007), h. 21. 


\section{8-74 | Syahida Yasya Moeniri}

berbeda. Berdasarkan sosiopsikiatris, mitra dakwah digologkan berdasarkan kelamin, usia, tingkat kecerdasan, tingkat pendidikan, pemikiran keagamaan, sikap keagamaan, kepribadian dan motivasi. ${ }^{15}$ Maka berdasarkan sosiopskikiatris target dakwah Like Islam Project adalah wanita dari SMP sampai kurang lebih lima puluh tahun. Like Islam Project memilih wanita sebagai targetnya karena latar belakang pelaku dakwah yang juga merupakan seorang wanita, sehingga pelaku dakwah lebih mengetahui karakter seorang wanita yang akan menjadi mitra dakwahnya sehingga lebih menyenangi aktifitas dakwah dengan komunitasnya yaitu sesama perempuan.

\section{d. Pemilihan Media Dakwah Sesuai dengan Kondisi dan Situasi}

Media dakwah yang digunakan harus dipilih dengan memperhatikan efektifitasnya sehingga media yang digunakan dapat membantu mencapai tujuan dakwah secara maksimal. Pemilihan dakwah yang efektif dipengaruhi oleh berbagai faktor yang terkait dengan unsur dakwah lainnya. Pendakwah harus memperhatikan pemilihan media dakwah yang sesuai dengan pesan yang akan disampaikan, mitra dakwah yang menjadi sasaran serta metode dakwah apa yang digunakan. ${ }^{16}$

Karena mad'ū Like Islam Project adalah wanita maka dipilihlah media marchandise, dimana wanita menyukai seni dan sastra dan tertarik pada penampilan diri. Media ini termasuk kedalam golongan The Printed Writing yang merupakan barang-barang tercetak, gambargambar tercetak, lukisan-lukisan, buku, surat kabar, majalah, brosur, pamfhlet, dan sebagainya. ${ }^{17}$

Dunia kini sudah berada dalam genggaman tangan seseorang dengan internet. Bahkan, ada sebuah fakta bahwa pengguna sebuah media sosial jauh lebih banyak dibandingkan jumlah penduduk sebuah negara ${ }^{18}$ Karena alasan inilah Like Islam Project memilih online store

\footnotetext{
${ }^{15}$ Akhmad Anwar Dani, Ilmu Dakwah, (Pamekasan: Cendekia, 2014), h. 19

${ }^{16}$ Ibid., h. 19 .

${ }^{17}$ Ali Aziz, Ilmu Dakwah, (Jakarta, Prenada Media, 2004), h. 121

${ }^{18}$ Rulli Nasrullah, Media Sosial, (Bandung: Simbiosa Rekatama Media, 2015), h. 3.
} 
sebagai media pemasaran produknya.

Meski masih terjadi perdebatan di kalangan umat Islam tentang diperbolehkannya online store, Like Islam Project tetap menggunakan media online store karena didalam proses jual beli Like Islam Project tidak terkandung unsur penipuan sama sekali dan apabila reseller tidak puas dengan hasil produksi, maka masih bisa di-restore.

Dalam Islam, transaksi apapun dan bagaimanapun kreasinya, selama tidak mengandung hal-hal yang menyebabkan terjadinya kerugian pada salah satu pihak yang bertransaksi dan barang yang diperjualbelikan bukanlah barang yang terlarang dan dilarang baik oleh hukum agama (syariat Islam). ${ }^{19}$

\section{e. Originalitas Ide dan Konsep}

Dalam dakwah diperlukan suatu karakteristik yang berbeda dari yang lainnya. Produk Like Islam Project merupakan produk yang lain yang belum ada di pasaran. Karakteristik produk Like Islam Project yakni selalu ada quotes-quotes dalam produknya, dan kebanyakan dilengkapi dengan gambar yang lucu. Nilai keaslian yang dimiliki oleh Like Islam Project adalah terletak di desain produk yang kreatif. Dan hal yang paling penting dari konsep produk ini adalah bisa berdakwah dengan menggunakan produk Like Islam Project yakni dakwah yang akrab dengan kehidupan sehari-hari dan ramah dengan masyarakat.

\section{Bentuk Dakwah Like Islam Project}

Like Islam Project sebagai home industry kreatif memiliki bentuk dakwah yang berbeda dari dakwah lainnya. Bentuk dakwah Like Islam Project bisa dikategorikan seperti berikut:

\section{a. Berdakwah dengan desain komunikasi visual melalui marchandise}

Like Islam Project menggunakan desain komunikasi visual, dimana desain komunikasi visual adalah ilmu yang mempelajari konsep komunikasi dan ungkapan daya kreatif, yang diaplikasikan dalam berbagai media komunikasi visual dengan mengolah elemen desain

${ }^{19}$ Shofiyullah Mz., dkk. "E-Commerce dalam Hukum Islam", Jurnal Penelitian Agama, Vol. 17 No. 3, (Sepetember-Desember, 2008), h. 579 . 
70-74 | Syahida Yasya Moeniri

grafis terdiri dari gambar (ilustrasi), huruf, warna, komposisi dan layout. Semuanya dilakukan guna menyampaikan pesan secara visual, audio, dan audio visual kepada sasaran target yang dituju. ${ }^{20}$

Desain komunikasi visual akan berkesan apabila dalam penyajiannya tersebut terdapat suatu keunikan sehingga ia tampil secara istimewa, mudah dibedakan dengan lainnya. Like Islam Project menggunakan desain komunikasi visual yang unik sehingga banyak orang yang tertarik dengan marchandise-nya..

\section{b. Posting-an foto}

Foto yang di-posting oleh Like Islam Project terbagi menjadi dua jenis.

1. Foto yang langsung berisi dakwah

Sebagai akun yang membawa nama Islam, Like Islam Project tidak hanya mem-posting produk yang akan dipasarkannnya, namun tak jarang pula Like Islam Project mem-posting foto yang berisi dakwah beserta catatan dakwah dari Like Islam Project.

2. Foto marchandise dakwah

Marchandise yang telah dibuat oleh Like Islam Project akan difoto dan di-posting di akun instagram Like Islam Project. Dari foto marchandise dakwah yang di-posting itulah orang-orang akan melihat esensi dakwah yang dilakukan Like Islam Project sekaligus memasarkan produknya.

\section{c. Syari'ah Kreatif}

Usaha dakwah Like Islam Project tidak hanya terletak pada marchandise-nya saja. Secara tidak langsung Antikah mengajak pelanggannya untuk menjauhi riba yakni dengan menggunakan bank syari'ah dalam proses transfer uang pembelian. Seperti yang telah dijelaskan penulis sebelumnya dalam strategi dakwah point "Memiliki visi yang jelas."

h. 5

${ }^{20}$ Sumbo Tinarbuko, DEKAVE Desain Komunkasi Visual, (Yogyakarta: CAPS, 2015), 
Syahida Yasya Moeniri: Like Islam Project | 71-74

\section{d. Memupuk jiwa saling mencintai}

Tindakan dakwah yang dianggap penting salah satunya adalah menghidup suburkan dan mengembangkan hidup tolong menolong, saling cinta mencintai, kebiasaan itsar dan solider. ${ }^{21}$ Hal inilah yang dilakukan oleh Like Islam Project dalam berdakwah, hal ini memang merupakan hal yang tidak kasat mata. Hal yang dilakukan oleh Like Islam Project untuk memupuk jiwa solidaritas sesama muslim yakni dengan memberikan hadiah kepada pelanggannya yang sedang semangat dalam berhijrah.

\section{e. Meningkatkankemampuan masyarakatdalamusahaperekonomiannya}

Salah satu tindakan dakwah yang yang dianggap penting yaitu meningkatkan kemampuan masyarakat dalam usaha perekonomiannya, sehingga masing-masing anggota masyarakat dapat mencukupi kebutuhan hidupnya tanpa menggantungkan diri kepada orang lain, bahkan dapat memanfaatkannya untuk kepentingan masyarakat. ${ }^{22}$

Like Islam Project melibatkan banyak orang dari proses awal pembuatan hingga dustribusi produknya, dan hal tersebut membuka peluang kepada orang-orang untuk memiliki pekerjaan. Puluhan orang bisa bekerja dari suatu home industry Like Islam Project. Orang-orang yang terlibat tersebut terdiri dari 7 Karyawan, 70-80 reseller, dan 8 distributor.

Dari semua bentuk-bentuk dakwah di atas, dapat dikatakan bahwa bentuk dakwah tersebut merupakan metode amatir, artinya tanpa mengikuti suatu sistem yang telah teruji efektivitasnya dan sekedar menurut kemampuan pribadi saja. ${ }^{23}$

\section{Penutup}

Latar belakang terbentuknya Online Store Like Islam Project bermula dari keinginan mencari kerja untuk memenuhi kebutuhannya namun juga

\footnotetext{
${ }^{21}$ Hasyim Syamhudi, Manajemen Dakwah, (Surabaya, elkaf, 2007), h. 110.

${ }^{22}$ Ibid., h. 111.

${ }^{23}$ Moh. Ali Aziz, Ilmu Dakwah, (Jakarta: Kencana, 2004), h. 187.
} 
72-74 | Syahida Yasya Moeniri

dilandasi dengan visi misi bersama suami yakni dakwah dan memberikan efek positif kepada orang lain. Sedangkan strategi dakwah yang dilakukan oleh Like Islam Project yang pertama yaitu memiliki visi yang jelas, tujuan Like Islam Project yaitu berdakwah dengan serius, santai dan syar'i. Strategi berikutnya adalah menyiapkan sumber daya manusia yang berkualitas meliputi pelaku dakwah yang harus expert dalam bidangnya, memiliki rasa optimisme, tidak kenal putus asa, berani menerima kegagalan untuk bisa menjadi lebih baik, pandai melihat peluang dalam setiap situasi dan kondisi, memiliki sifat-sifat yang sangat dianjurkan oleh Islam seperti sabar, tawakal, selalu bersyukur, berani dan berpikir positif, serta berjiwa besar menerima kritikan dari berbagai pihak. Strategi yang ketiga adalah menentukan target (Mad'u) yang dalam hal ini merupakan perempuan, lalu memilih media dakwah sesuai kondisi dan situasi meliputi marchandise dakwah dan online (social media), serta memiliki nilai originalitas ide dan konsep. Bentuk dakwahLike Islam Project terdiri dari:dakwah dengan desain komunikasi visual melalui marchandise, posting-an foto, syari'ah kreatif, memupuk jiwa saling mencintai dan meningkatkan kemampuan masyarakat dalam usaha perekonomiannya. Kepada peneliti selanjutnya, jangan jadikan alasan ruang dan waktu menghambat penelitian anda. Karena didalam kesulitan akan terdapat kemudahan.

\section{Daftar Pustaka}

Ahmad, Fadil Ibnu. Dakwah Online. Bandung: Mizania, 2014. Arifin, Anwar. Dakwah Kontemporer. Yogyakarta: Graha Ilmu, 2011 Aziz, Moh. Ali. Ilmu Dakwah. Jakarta: Kencana, 2004.

Batubara, Abdul Karim. Pemanfaatan Media Komunikasi Massa Sebagai Sumber Informasi. Iqra', Volume o2 Nomor o1, 2008.

Dani, Akmad Anwar, Ilmu Dakwah Kompilasi Materi Pokok Kajian Ilmu Dakwah. Pamekasan: Cendikia Press, 2014.

Departemen Agama RI. Al-H\{ikmah al-Qurān dan Terjemahnya. Bandung: Diponegoro, 2010. 
Syahida Yasya Moeniri: Like Islam Project | 73-74

Hasyim Syamhudi, M. Manajemen Dakwah. Surabaya: Elkaf, 2007.

Ibrahim, Idi Subandy \& Bachruddin Ali Akhmad. Komunikasi dan Komodifikasi. Jakarta: Yayasan Pustaka Obor Indonesia, 2014.

Muhtadi, Asep Saeful dan Agus Ahmad Safei. Metode Penelitian Dakwah. Bandung: Pustaka setia, 2003.

Nasrullah, Rulli. Media Sosial Perspektif Komunikasi, Budaya, dan Sosioteknologi. Bandung: Simbiosa Rekatama Media, 2015.

Saebani, Beni Ahmad. Metode Penelitian. Bandung: CV Pustaka Setia, 2008. Shofiyullah Mz., dkk. E-Commerce dalam Hukum Islam, Jurnal Penelitian Agama, Vol. 17 No. 3, (Sepetember-Desember, 2008).

Tinarbuko, Sumbo. DEKAVE Desain Komunikasi Visual. Yogyakarta: CAPS, 2015 .

Waluyanto, Heru Dwi. Komik Sebagai Media Komunikasi Visual Pembelajaran. Nirmana, Vol. 7, No. 1, 2005. 